\title{
“O GRÃO DE ARROZ E O PRECIPÍCIO”, SEGUIDO DE AFORISMOS UM TANTO INÓSPITOS
}

\author{
Leonardo Lima Ribeiro ${ }^{1}$
}

\section{O grão de arroz e o precipício}

Certo dia, após comer histericamente em uma das mesas da sucateada Universidade Estadual do Ceará, pude apreciar uma das mais extravagantes cenas da geografia dessa instituição. Essa apreciação teve o seu prelúdio quando alguns resíduos alimentares tocaram os meus olhos a distancia, por meio da vibração de luz que deles se emanava sob a intensidade dos ritmos das cores branca e marrom. Pois bem, esses resíduos, os quais haviam de antemão saltado de minha boca e se alocado impositivamente em cima de uma das mesas verdes que ocupavam trechos de distorcido jardim expressionista, eram precisamente um grão de arroz e um de feijão.

Então, a cena se delineava a partir da planície de uma mesa ocupada por arroz e feijão, mesa a qual era sustentada pela fina base ou bloco de cimento acompanhado de seus insolentes e rijos tijolos. Assumindo para nós a perspectiva do feijão e do arroz decaídos, o limitado cume da mesa seria um precipício relativo ao solo que a abraçava pelos pés! Mas por que me impressionar aqui com isso, quando se sabe que ao passo em que arroz e feijão saltam ornamentalmente de nossos lábios eles buscam perseverar estáticos em cima de, por exemplo, uma mesa como aquela, evitando sofrer, pelo menos em aparência, qualquer empurrãozinho das umedecidas ventanias do litoral de Fortaleza?

Respondo a isso dizendo que enquanto o feijão e o arroz se mantinham imponentemente fixados sobre aquela planície esverdeada da mesa, que tentava imitar pateticamente os tons das belas gramíneas dos aristocratas campos de golfe, minimalistas formigas negras emergiam do interior do cume daquela mesa. E então disse para três amigos [Eduardo, Alberto e Janaína] que me acompanhavam também como espectadores da cena em descrição: "agora fodeu”. As formigas iriam certamente arremessar precipício abaixo arroz e feijão.

Enquanto um grupo de formigas fixava-se em torno das sinuosidades do arroz, outro grupo determinava-se ambiciosamente a levar para casa o caroço de feijão. Esse último certamente era denso, de um marrom excessivamente pesado. Foi isto que

\footnotetext{
${ }^{1}$ Mestre em Filosofia pela Universidade Estadual do Ceará.
} 
certamente o impediu de ser raptado. Talvez a obesidade respectiva a qualquer ente vivo seja realmente uma virtude ao longo dos impulsos ensandecidos por meio de que a vida parece se transformar de um só golpe numa boca faminta prestes a fazer o mundo explodir por meio de enormes mastigadas de ratos, homens, porcos, lebres, dinossauros e formigas. Tudo está com fome nesse universo, nele tudo é digerível e defectivelmente escatológico. Se houver um panteísmo filosófico que ele seja o da degustação!

Pois bem, o feijão, até o momento em que o observei, não pôde ser empurrado precipício abaixo, desfiladeiro que continha em seu pano de fundo aquelas pequenas pedras as quais não permitem os transeuntes caminharem confortavelmente nas universidades. Mas essa é uma característica precisa das universidades, elas são a própria encarnação do desconforto sob as instâncias mais variadas, intelectuais, administrativas ou alimentícias. E o arroz? Ah, esse sim enfrentou um sério problema, apesar de tê-lo superado. Como aquele grão de arroz iria se desfazer da verdadeira miragem da profundeza a qual estava destinado a entrar em contato?

O arroz começou a ser arrastado sobre as costas de seis ou sete pequenas formigas, que pareciam goleiras as quais não sabiam cooperar com as partidas de futebol, porquanto não devolviam por nada aquela metáfora de bola [o arroz] ao restante do time. A aderência entre arroz e formigas era gótica, pois formavam juntos uma espécie carro alegórico participante de um carnaval tentacularmente distorcido. Fora exatamente essa alegoria que se apoderara de um impulsivo movimento em direção àquele abismo, que certamente teria seu momento de anunciação, com todo o magnetismo que faria até mesmo homens medíocres sentirem algo estranho, tal como calafrios das profundezas do desconhecido. É sabido, as formigas sobreviveriam. Mas e o arroz? Para mim, seria empurrado e posteriormente degustado à base de terra e pedras pelos bichanos.

Então, como se desfecha essa delicada situação? Observando o que realmente acontecia, percebia que tudo o que construía em mim a partir de impressões sensíveis não passavam de previsões falaciosas acerca do futuro do grão de arroz. Todas as conjecturas que havia predeterminado interiormente não condiziam ou sequer conduziam à realidade do desfecho deste curto texto. E qual era essa realidade que parecia ser totalmente desfavorecida pelas fantasias de minha tosca vidência, a qual tanto se aproximava, pelo menos naquele momento, das divinas previsibilidades costumeiramente anunciadas por cartomantes mixurucas? Ao contrário das minhas inferências anteriores, o desfecho dessa realidade não se deu por meio do desmembramento daquele carro alegórico, ou mesmo 
pela dissolução de certo plano de composição móbil que havia se fabricado a si mesmo como pitoresco personagem no mundo. Ou seja, o arroz não fora suicidado pelas formigas, não fora arremessado em direção àquele abismo de pedras inóspitas as quais cotidiana e sadicamente atormentam as solas dos pés dos universitários.

Sempre pensei que tais pedras fossem como botes defeituosos que pareciam dizer aos discentes que a planície a qual eles esmagam todos os dias não lhes torna realmente senhores de si, mas, do contrário, arrasta-os para uma contínua instabilidade espiritual. E realmente, o solo da universidade é uma de espécie de mar tempestuoso que faz emergir insanamente das profundezas de si botes defeituosos, pedregosos. Com efeito, os pequenos barcos não são salva-vidas, mas são aquilo que destrói pouco a pouco a beleza espiritual de cada homem que passa a acreditar estar salvaguardado em seu interior a partir da divina sapiência que adquire dos docentes e das referências bibliográficas. Sincera e eticamente falando: eu não gostaria que aquele grão de arroz chegasse sequer a tocar aquelas terras oceânicas destruidoras da inocência humana. E, por acaso, essa não era apenas uma preocupação minha, mas também das próprias formigas que o arrastavam! Elas jamais permitiriam que aquele grão de arroz se esparramasse em terra que nada fertiliza de beleza.

É por isso que ao se aproximarem do fim do cume da mesa, começaram a realizar algo análogo ao que os homens aventureiros denominam de rapel. Com essa prática esportiva, iniciaram a descer pelas paredes verticais do precipício da mesa. Parecia uma espécie de desfile exibicionista que demonstrava uma descomunal força de sustentação do grão de arroz em seis ou sete costas nos rumos do inóspito solo universitário.

Isso acontecera até o momento em que aquelas negras formigas desapareceram em certas fendas, levando consigo o grão de arroz. Fora uma caminhada interna à mesa e que perdurara até o momento em que puseram o resplandecente grão de arroz em contato com uma tribo de insetos. Esses o veneraram e, consequentemente, o despedaçaram pelas forças extravagantes de seus pequenos estômagos. Foi justamente desse modo que grão de arroz pôde curar-se por definitivo da vertigem do precipício que o levaria a desaguar no solo em que se assentam cotidianamente os ensandecidamente paradoxais homens de academia.

\section{O preenchido do saber}


Conheço sim, conheço o bastante dos autores para ter perdido a consciência de quem sou. Tornei-me um receptáculo de informações, de tinta antiquada de textos velhos. Acredito que eles me tornaram superior, isto é, acima de qualquer associado do vulgo, justamente por defender, replicar as informações autorais dos outros na mesma e intensa medida em que me perco de mim. Com tantas informações acumuladas também reneguei para mim a procura de mim. Tornei-me arrogante, tal arrogância insurgiu a partir da absorção dos outros, quando me sintetizei em páginas vazias completadas por alguns parágrafos textuais. Agora não passo de uma memória de livros postos no interior de um espírito sem originalidade, um fluxo espiritual que sobrevoa e observa por dentro de seu corpo o universo das cópias impressas, o que proporciona um organismo fragilizado pelos conhecimentos. Qual deles escolherei para falar? Qual deles utilizar para reiterar a "egologia" de seus escritores? Agora não sei como superar essa profunda cacimba de mediocridade a qual me tornei, porquanto também não tenho sido mais do que um homem cujos livros se apossaram. O que é melhor, ser alienado relativamente aos objetos da pescaria, do amor ou da celulose? Poderia dizer que acabei me resumindo a uma folha de papel ofício falante em que os filósofos e literatos estão continuamente a escrever na superfície, contando na surdina as suas histórias de vida. E aqui e acolá ainda me reconheço poderoso, mesmo sabendo que extirparam de mim a força afirmativa de minha própria singularidade! Um grande paradoxo, aquele de um homem que adquiriu a vaidosa exuberância de saber e que, no entanto, tem sempre a dizer o que nunca lhe pertenceu. Contudo, escrevo a partir de agora de modo inteiramente oposto, ou seja, sem o sentimento da culpa originária que me importunava pelo ato de forçar-me a estar sob o crivo das referências, ícones. Melhor agora, para não refugiar-me completamente de mim, dar tapinhas nas bundas dos autores que estão em minha memória, acabar com seus mimos, seus quereres de exposição. Não direi mais a quem devo os meus pequenos textos. Talvez esse ato de traição seja a própria força de uma vida reecontrada, a minha, que reecontro agora sob a medida da força extrema advinda de uma desmedida bandidagem.

\section{Esconjurando princípios}

A memória de você me corrói. Arrasta-me por um impulso degenerador, instanciado abaixo desta frágil pele. E então? Deixo as tuas imagens me degenerarem, galgarem cada uma das minhas artérias e espremê-las até o sangue jorrar, vazar pela narina 
como secreção? Isso tudo é muito soturno. Como me comover com sua essência natural se ela reflete-se em mim claustrofobicamente por meio de imagens memoráveis, acontecimentos imperativos, absolutos. Que diabos de negrume luminoso tu pregaste aqui dentro? Por acaso pensa que não reagirei a tua imagem em minha cruz vertebrosa? Evito até os ícones de Jesus de se pendurarem em mim, imagine você e suas imagens filosóficas. O interior do meu corpo não é árvore seca com galhos para macaquear. Não respeitas a privacidade de meu corpo pudico? Invade-o assim? Não posso te processar por invasão domiciliar, tendo em vista a trágica comédia da miscelânea de emissões as quais você deixou em mim e que não param para serem capturadas às claras. Nenhum dia a polícia te pega, as entidades federais, digamos assim, os médicos, acabaram de me investigar por dentro, com raios-x e ressonâncias magnéticas. Não te encontraram, só eu te vejo, só eu enlouqueço por me tornar homólogo a você dentro da minha própria terra. Com efeito, minha esquizofrenia, ocasionada por você em mim, é “inuniversalizável” e, por conseguinte, relativa. Te sinto à minha maneira, para melhor ou para pior. Ao fim e ao cabo, sem querer te sigo dia e noite para entender os teus próximos passos ao longo dos meus músculos fragilizados, magoados por tuas altivas e andarilhas expressões em mim: DEIXA-ME MORALIZADOR DE ARAQUE. Não sou nietzschiano, mas paciência. Aceito um pouco de ti, sem dúvida, mas Todo o teu ser?! Por que não me pedira antes com calma, primeiramente com aulas de mímica e, em seguida, com o velho $K Y$ [ou com cuspe mesmo], penetrando-me num quarto luminoso? Mas não, em temáticas acerca da invasividade em torno das sombras você é especialista. Está sempre por trás, nas sombras, e é imperceptível. Seu porra! Algemou-me por inteiro com os teus princípios. Meu corpo tornou-se cadeia após o teu estupro. Não resta mais nem chorar, pois nem a mim mesmo eu irei recuperar. Hora de partir sem mais tardar, por meio de um empreendimento que fará, por definitivo, as tuas sábias imagens serem destronadas pelos vermes malditos assentados sob a terra mesclada às águas barrentas dos cemitérios envolventes do mar.

\section{A terra e a transfusão da humildade}

Descobri há pouco que giro em torno do fogo, fogo o qual queima esta pele vivente operante cronicamente. Rastros de luz imprimem-se sobre a minha superfície epitelial, até o momento em que não mais poderei obter para mim as fagulhas desse inexorável jorro solar. Quando as terras do subterrâneo mundo opaco [de barro ou não] 
me contornarem e subsequentemente me tocarem, fissurando e abrindo fendas em meio ao caixão que pagarão tão caro no intuito de me preservar, certamente não mais terei condições de verbalizar acerca de qualquer quantidade de luz, porquanto não serei mais um verdadeiro empreiteiro do sensível. Provavelmente, as noites sombrias da morte no subsolo me tornarão mais humilde, ao denotarem que estarão a me humilhar pelo fato de que me farão calar para o que sinto, uma vez que também não mais sentirei. Isso se dará quando eu não mais puder ser aquele orgânico espaço predeterminado para os assentamentos e aferições daquilo que me fora, em minha crença, a própria divindade solar. Com efeito, acredito que é em minha morte que as prescrições meu deus solar e eu enquanto verbalizador sensivel desse deus se porão a me abandonar.

\section{Silencioso abismo}

O subsolo da vida no mundo é uma grande insenbilidade. Se a vida regenera na exata medida em que aniquila, é certamente insensivel frente a qualquer experiência a qual será agrupada e encadeada enquanto uma montanha de lixo psicológico em mim, por exemplo; e a experiência sensível com seus dados, portanto, não passa de alegoria em meio àquilo que impudicamente não a respeita de modo algum, a saber, a própria vida a qual se afirma ao passo que preserva degenerando. As experiências sensíveis conscientes são realmente ilusões caóticas que nos escondem o fato instransponível da sórdida realidade determinante. Com efeito, a primeira verdade do mundo não está imersa na sensibilidade orgânica diante do próprio mundo, mesmo quando é tendência a legitimação costumeira dessa sensibilidade orgânica enquanto critério de realidade, ao chamá-la de relativa mediante cada um dos homens que experimenta a seu modo a matéria. Se a vida destrói cronicamente o fato de um organismo continuar a sentir e acumular experiências nas passadas em que progride, na ilusão da conservação, rumo à velhice, a vida é certa e primeiramente insensível, pois não tem o menor pudor perante o que tal organismo sente conscientemente ou resguarda em si a partir dos órgãos dos sentidos. Ouvir, sentir, cheirar são percepções conscientes da e na vida, atos verbais dados metaforicamente por meio dos órgãos dos sentidos. Esses atos do ouvir, sentir e cheirar são na verdade aquilo a partir de que se dobra local e incansavelmente as vibrações da silenciosa insensibilidade interna aos homens e às outras espécies. Isso se dá porque independente da consciência do que se sente, ouve e cheira, imperceptível e insensivelmente acumulamos vida anorgânica. Ou seja, 
a priori vivemos a vida sem sabermos conscientemente que a vivemos na potência de sua insensibilidade. É possivelmente isso que costumeiramente a própria consciência humana não se habitua a perceber, justa e paradoxalmente o seu primeiro motor. É do insensível que se há a permissividade aos órgãos dos sentidos para limitada acumulação de experiências conscientes, ou melhor, toda experiência consciente é em verdade uma tomada de consciência de que, para além da própria consciência, se está sob o crivo despótico do inconsciente vivo que nos perpassa. Eis a gélida e covarde maldição em nós, arrastando-nos para abismos devidamente intransponíveis, os quais nos enganam com o embuste factual pelo qual cremos indevidamente que nos conservamos. 